\title{
ARAH POLITIK HUKUM NASIONALTERHADAP KESEJAHTERAAN SOSIAL DALAM KERANGKA KONSTITUSI EKONOMI DI INDONESIA
}

\section{Fuqoha}

Fakultas Ilmu Sosial, Ilmu Politik dan Ilmu Hukum, Universitas Serang Raya, Kota Serang, Banten.

Correspondent email : fuqoha23@gmail.com

\begin{tabular}{|lll}
$\mid$ Article History & $:$ & \\
$\mid$ Submission & $:$ & 1 November 2021 \\
$\mid$ Last Revissions & $:$ & 25 Desember 2021 \\
|Accepted & $:$ & 28 Desember 2021 \\
| Copyedits Approved & $:$ & 30 Desember 2021
\end{tabular}

\begin{abstract}
Economic constitution has become a new idea within the constitutional framework as the basic foundation for the development of the national and global economy. National economic policies in the context of realizing social welfare must be able to guard and control the national economic system. Apart from the legal politics policy and the government's power in determining the direction of national policy, the conception of the economic constitution as the basic foundation must be realized. This study intends to describe the politics of national law and the concept of economic constitution in realizing social welfare. This research method uses normative juridical research using an exploratory descriptive analytical approach. The characteristics of national legal politics in practice still influence the realization of national economic policies, even though it has implied the concept of an economic constitution in the 1945 constitution. Social welfare, which is the goal of the state, becomes a political tool for national law through a national economic system that cannot be separated from political power.
\end{abstract}

Keywords: Constitution; Economy; Welfare; Politics of Law; 


\section{A. PENDAHULUAN}

Hukum sebagai suatu entitas keilmuan merupakan suatu disiplin ilmu yang dapat terus berkembang yang dapat dilihat dari berbagai aspek serta dimensi. Oleh karena itu, kompleksitas hukum yang dapat dikaji dari perspektif keilmuan tersebut mengakibatkan luasnya kajian dari ilmu hukum. Kompleksitas yang ada pada ilmu hukum itu dapat dipelajari dari berbagai aspek keilmuan sebagai disiplin hukum seperti teori hukum, sejarah hukum, sosiologi hukum, antropologi hukum, perbandingan hukum, logika hukum, psikologi hukum dan terakhir adalah politik hukum. ${ }^{1}$ Hukum sebagai entitas ilmu yang sangat kompleks yang dapat dikaji dalam kerangka politik hukum yang mengkristalisasi kehendak-kehendak politik yang saling bersaingan dalam pemberlakuan suatu aturan, regulasi, kebijakan hukum sehingga latar belakang politik tertentu dapat melahirkan hukum dengan karakter tertentu. Oleh karena itu, politik hukum dipandang sebagai suatu kerangka keilmuan yang menelaah konsep bagaimana politik mempengaruhi hukum atau hukum mempengaruhi politik dalam penyelenggaraan negara dan bangsa.

Hukum sebagai kaidah atau norma sosial tidak terlepas dari nilai-nilai yang berlaku dalam suatu masyarakat, bahkan dapat dikatakan bahwa hukum itu merupakan pencerminan dan konkretisasi dari nilai-nilai yang berlaku dalam masyarakat. Namun demikian, setiap kebijakan hukum dan aturan hukum yang diberlakukan tidak tertutup kemungkinan dipengaruhi oleh aspek-aspek atau nilai-nilai lainnya seperti sosial, ekonomi dan politik. Sehingga dalam perumusannya, kebijakan hukum akan sangat ditentukan oleh aspek-aspek tersebut, termasuk politik yang kemudian dikenal dengan istilah politik hukum. Definisi dari politik hukum beberapa telah diuraikan oleh para ahli hukum seperti Satjipto Rahardjo yang mengartikan politik hukum sebagai aktifitas untuk menentukan suatu pilihan mengenai tujuan dan cara-cara yang hendak dipakai untuk mencapai tujuan hukum. Sedangkan Purnadi Purbacaraka dan Soerjono Soekanto mengartikan sebagai kegiatan memilih dan menerapkan nilai-nilai. Selain diartikan sebagai cara yang dipilih serta nilai-nilai yang dituangkan, politik hukum juga dapat dilihat dari isi peraturan perundang-undangan. ${ }^{2}$

Politik hukum jika dilihat dari sifatnya memiliki sifat local dan particular, hal tersebut menunjukkan sudut pandang dalam pengimplementasian hukum dalam kerangka kekuasaan negara. Sifat tersebut merujuk pada world view atau pandangan hidup bebangsa dan bernegara, sociocultural dan political will dari suatu pemerintah kekuasaan. ${ }^{3}$ Dengan kata lain, kedudukan politik hukum sebagai kajian keilmuan

\footnotetext{
${ }^{1}$ Imam Syaukani and A. Ahsin Thohari, Dasar-Dasar Politik Hukum, Cet. Ke-11 (Depok: Rajawali Press, 2018). hlm. 2

${ }^{2}$ Bergas Prana Jaya, Dasar-Dasar Pengantar Ilmu Hukum, Cet. Ke-1 (Yogyakarta: Legality, 2019). hlm. 49

${ }^{3}$ Ibid. hlm. 50
} 
merupakan suatu landasan tindakan dalam pelembagaan, proses dan penegakkan hukum sesuai dengan kehendak penguasa.

Politik hukum sebagai legal policy atau garis kebijakan resmi tentang hukum yang akan diberlakukan baik dalam pembaharuan hukum maupun pergantian hukum lama. ${ }^{4}$ Dengan kata lain, politik hukum itu pilihan penguasa tentang hukum-hukum apa yang hendak diberlakukan, sekaligus pilihan tentang hukum-hukum yang ditiadakan dalam rangka mencapai tujuan negara. Merupakan kenyataan bahwa setiap pemerintahan memiliki tujuan yang harus dicapai dimana dalam konsep negara hukum upaya mencapai tujuan tersebut harus didasarkan pada hukum mengkonsepsi hukum sebagai alat.

Kajian Politik hukum digunakan sebagai alur berfikir atau untuk memahami karakteristik suatu undangundang dalam sistem hukum yang diberlakukan suatu negara. Konsepsi politik hukum dalam pemikiran Mahfud MD yang mengatakan hukum sebagai produk politik yang memberi makna suatu "legal policy" menunjukan suatu peraturan perundang-undangan atau regulasi sarat akan kepentingan politik. Meskipun dalam hakikatnya kehidupan berbangsa dan bernegara tidak akan pernah terlepas dari faktor politik sebagai sarana interaksi antara pemerintah (penguasa) dengan masyarakat dalam rangka pembuatan dan pelaksanaan keputusan untuk memperoleh kebaikan bersama. Politik hukum memiliki arti penting bagi terbentuknya suatu produk hukum khususnya perundangan-undangan dan kebijakan hukum nasional. Oleh karena itu, diperlukan sebuah pemahaman yang mendalam bagi seluruh subyek negara yang terlibat langsung maupun tidak langsung dalam proses pembentukan peraturan perundang-undangan dan/atau kebijakan hukum di Negara Indonesia.

Negara Indonesia sebagai negara hukum sebagaimana ketentuan Konstitusi Negara Republik Indonesia berimplikasi pada tatanan negara yang dilandaskan pada hukum dan perundang-undangan sebagai dasar penyelenggaraan negara. Oleh karena itu, negara melalaui pemerintahan terus berupaya untuk melakukan pembangunan hukum di Indonesia dengan cara memperbaiki, mengganti atau menyempurnakan setiap kebijakan hukum meliputi UUD 1945, undang-undang, hingga peraturan lainnya. Dalam praktiknya pembangunan hukum akan dipengaruhi oleh kekuatan politik (arah politik) penguasa yang dimulai dengan menata kembali tertib hukum dan tata-urut peraturan perundangundangan yang sejalan dengan karakteristik penguasa. Dengan demikian dalam membangun susunan perundang-undangan yang dapat dijadikan acuan bagi upaya memantapkan perundang-undangan yang akan dijadikan landasan mencapai tujuan negara secara periodik maupun di masa depan, perumusan dan pengembangan kebijakan hukum akan sangat ditentukan oleh kekuasaan politik. Dalam menyikapi persoalan perkembangan hukum nasional ini, sepertinya perlu suatu upaya untuk melakukan

\footnotetext{
${ }^{4}$ Deddy Ismatullah and Enung Nurjanah, Politik Hukum, Kajian Hukum Tata Negara, Cet. Ke-1 (Bandung: Remaja Rosdakarya, 2018). hlm. 61
} 
penataan kembali pada suatu pelembagaan hukum dengan didukung kualitas sumberdaya manusia dan kesadaran hukum masyarakat yang terus meningkat, seiring dengan pembaruan materi hukum yang terstruktur secara harmonis, dan terus menerus diperbarui sesuai dengan tuntutan perkembangan kebutuhan.

Politik hukum pada akhirnya akan menunjukkan karakteristik suatu kebijakan hukum yang didasarkan pada prinsip dan sistem politik negara. Oleh karena itu, karakteristik akan sangat berpengaruh pada tatanan implementasi, restrukturisasi dan implikasi suatu produk hukum. Dalam karakteristik sistem hukum di Indonesia tidak terlepas dari faktor ideologi negara, sebagaimana ketentuan dalam peraturan perundangundangan mengenai pemebentukan undang-undang bahwa landasan dasar pemebentukan perundang-undangan di Indonesia bersumber pada ideologi pancasila. Dengan demikian, maka pancasila dapat dijadikan sebagai dasar karakter politik hukum nasional selain faktor sistem hukum yang telah terimplementasikan dalam kerangka hukum nasional.

Praktik pengimplementasian suatu kebijakan hukum dalam kerangka hukum nasional dibentuk melalui tatanan yang tersusun dalam program legislasi, baik dalam bentuk program legislasi nasional maupun program legislasi daerah sebagaimana amanat kontitusi tentang otonomi daerah. Oleh karena itu, program legislasi menjadi salah satu instrumen yang menentukan dalam proses pengaruh politik atau kekuasaan terhadap suatu kebijakan hukum yang akan diberlakukan. Penentuan suatu program legislasi yang menunjukan arah dari suatu politik hukum nasional tidak terlepas dari tujuan dan kepentingan nasional dan/atau kepentingan negara. Salah satu amanat konstitusi adalah kesejahteraan sosial sebagaimana tertuang dalam konstitusi atau undang-undang dasar negara Republik Indonesia 1945 dalam BAB XIV tentang perekonomian nasional dan kesejahteraan sosial.

Kesejahteraan sosial menjadi tanggungjawab negara melalu program-program dan kebijakan-kebijakan yang berkaitan dengan ekonomi nasional. Hal tersebut dapat terlihat dari gagasan amandemen konstitusi negara Republik Indonesia yang menempatkan perekonomian nasional dan kesejahteraan dalam satu pembahasan sebagaimana dituangkan dalam Pasal 33 dan Pasal 34 Undang-Undang Dasar 1945. Menelaah gagasan Jimly Asshiddiqie mengenai perekonomian nasional dan kesejahteraan sosial yang diamanatkan dalam konstitusi yang disebut dengan istilah konstitusi ekonomi. Konstitusi ekonomi dimaknai sebagai bentuk konsep ekonomi yang dituangkan dalam kerangka hukum, hal tersebut didasarkan bahwa ilmu ekonomi berbeda dengan kebijakan ekonomi. ${ }^{5}$ Oleh karena itu, praktik perekonomian nasional hendaknya diselaraskan secara konstitusional dalam bidang ekonomi sehingga dapat mewujudkan kesejahteraan sosial.

\footnotetext{
5 Jimly Asshiddiqie, “Konstitusi Ekonomi (Ekonomi Pasar, Demokrasi Dan Konstitusi),” jimly.com, 2018, http://www.jimly.com/makalah/namafile/164/Pengantar_Ekonomi_Konstitusi.pdf.
} 
Negara yang pertama kali memasukkan kebijakan arah ekonomi ke dalam konstitusinya ialah Rusia yang pada saat itu bernama (The Russian Soviet Federative Socialist Republic-SFSR) Soviet-Russia di tahun $1918 .{ }^{6}$ Dari konsepsi kebijakan ekonomi yang dilandaskan pada konstitusi telah memberikan pondasi pemikiran pada berbagai negara dan termasuk Indonesia untuk menerapkan konsep konstitusi ekonomi sebagaimana tertuang dalam Undang-Undang Dasar Negara Republik Indonesia 1945. Didasarkan pada perkembangan konstitusi dan ekonomi yang berimplikasi pada kepentingan nasional menjadikan konstitusi ekonomi sebagai arah kebijakan politik hukum. Oleh karena itu, pengembangan hukum ekonomi nasional akan dipengaruhi oleh kekuasaan politik dan karakteristik politik hukum.

Konsepsi konstitusi ekonomi berpijak pada hukum sebagai dasar implementasi perekonomian, sehingga ekonomi tidak hanya diimplementasi sebagai suatu upaya dan usaha sebagaimana ilmu ekonomi. Dilandaskan pada prinsip konstitusi, maka penyelenggaraan perekonomian nasional dijadikan sebagai kebijakan dalam bentuk regulasi, sehingga praktik ekonomi merupakan representasi ketentuan hukum baik melalui konstitusi maupun regulasi-regulasi sebagai bentuk kebijakan hukum. Dinamika perekonomian nasional dalam rangka mewujudkan kesejahteraan sosial akan selalu dipengaruhi oleh faktor kekuasaaan politik yang berimplikasi pada arah kebijakan politik hukum nasional. Oleh karena itu, bagaimana arah politik hukum nasional sebagai identitas konstitusi ekonomi dan bagaimana karakteristik kekuasaan politik dalam mewujudkan kesejahteraan sosial dalam kerangka konstitusi ekonomi.

\section{B. METODE PENELITIAN}

Metode yang digunakan dalam penelitian adalah pendekatan yuridis normatif. Pendekatan dalam penelitian yuridis normatif berupaya mengkonsepsikan aturan hukum sebagai kaidah untuk menganalisis data secara sistematis dengan peraturan-peraturan yang ada. ${ }^{7}$ Sedangkan model penelitian yang disuguhkan yaitu model penelitian kualitatif dengan pendekatan deskriptif analitis untuk menggambarkan fakta-fakta secara sistematis dan terintegrasi. Penelitian kualitatif mengarah pada eksplorasi suatu makna yang timbul dari dinamika sosial. ${ }^{8}$ Sumber data yang dihimpun diambil dari studi kepustakaan yang didasarkan pada peraturan perundang-undangan dan konstitusi negara Republik Indonesia sebagai bahan primer dan buku, jurnal, dokumen-dokumen dan internet/website sebagai bahan sekunder.

\footnotetext{
${ }^{6}$ Agnes Harvelian, "Mahkamah Konstitusi Dan Penguatan Konstitusi Ekonomi Indonesia,” Jurnal Konstitusi Vol. 13, No. 3 (2016): 530, https://doi.org/10.31078/jk1333. hlm. 532

${ }^{7}$ Soerjono Soekanto and Sri Mamudji, Penelitian Hukum Normatif (Jakarta: Rajawali Press, 2006). hlm. 14

${ }^{8}$ John W. Creswell, Research Design, Pendekatan Kualitatif, Kuantitatif Dan Mixed, Third Ed. (Yogyakarta: Pustaka Pelajar, 2015). hlm. 4
} 


\section{HASIL DAN PEMBAHASAN}

\section{Karakteristik Politik Hukum Nasional Dalam Kerangka Konstitusi Ekonomi}

Karakteristik politik hukum dalam disiplin ilmu hukum oleh Purnadi Purbacaraka dikatakan sebagai suatu kajian yang khas sebagai salah satu ajaran tentang hukum dimana politik hukum memiliki keterkaitan antara teori dan filsafat hukum. Oleh karena itu, politik hukum dipandang sebagai ilmu hukum yang mengkaji tentang penemuan hukum (rechtsvinding) dan pembentukan hukum (rechtsvorming). ${ }^{9}$ Dalam pandangan Purnadi Purbacaraka dapatlah dijadikan sebagai dasar berfikir bahwa politik hukum merupakan salah satu kajian keilmuan mengenai proses penemuan hukum dan pembentukan hukum yang disesuaikan dengan konteks situasional dan kondisional suatu bangsa, yang dipengaruhi oleh kultur dan budaya bangsa, serta dipengaruhi oleh ideologi dan nilai-nilai religius yang dianut oleh bangsa dan negara.

Politik hukum dalam kerangka hukum tata negara oleh Faisal Sulaiman ${ }^{10}$ ditafsirkan sebagai kebijakan dasar penyelenggara negara dalam bidang hukum yang akan, sedang, dan telah berlaku, yang bersumber dari nilai-nilai yang berlaku di masyarakat dalam rangkan mencapai tujuan yang dicita-citakan. Maksud dari penafsiran Faisal Sulaiman terhadap politik hukum sebagai suatu pilihan pada kebijakan hukum yang digunakan oleh penguasa negara baik yang telah berlaku, yang baru diberlakukan, maupun yang akan (masih dalam rancangan) diberlakukan dipengaruhi oleh nilai-nilai yang hidup dimasyarakat dan/atau falsafah hidup bangsa dan negara.

Falsafah hidup bangsa dan negara Indonesia merujuk pada ideologi bangsa dan negara Indonesia yang bersumber pada pancasila. Dalam kerangka hukum, maka kedudukan pancasila adalah sumber dari segala sumber hukum sebagaimana dituangkan dalam kerangka konstitusi maupun dalam prasyarat pembentukan peraturan perundang-undangan yang tertuang dalam Pasal 2 Undang-Undang Nomor 12 Tahun 2011 Tentang Pembentukan Peraturan Perundang-Undangan bahwa pancasila merupakan sumber segala sumber hukum negara.

Makna ideologi diuraikan Edward Shill sebagai nilai-nilai dan pandangan masalah yang dianggap pokok melalui penjabaran penguasa yang memiliki kepentingan akan ideologi tersebut, serta ideologi menuntut ketaataan dari rakyat agar memelihara ideologi secara konsensus dan sangat peka terhadap penyimpangan

\footnotetext{
${ }^{9}$ Purnadi Purbacaraka and M. Chidir Ali, Disiplin Hukum (Bandung: Citra Aditya Bakti, 1990). hlm. 2

${ }^{10}$ Ismatullah and Nurjanah, Op.cit. hlm. 21
} 
terhadap ideologi tersebut. ${ }^{11}$ A. Hamid S. Attamimi menempatkan pancasila sebagai dasar yuridis dan ideologis, dimana pancasila dalam konotasi yuridis melahirkan berbagai macam perundang-undangan yang tersusun secara hierarkis dengan sumber pancasila. Sedangkan sebagai ideologi dikonotasikan sebagai program sosial politik yang menjadikan hukum sebagai alat yang sumbernya adalah pancasila. ${ }^{12}$

Implementasi pancasila sebagai pandangan hidup bersama dalam aspek-aspek hukum yang terumuskan didalam sistem hukum di Indonesia berimplikasi pada pemahaman nilai-nilai pancasila yang harus ditanamkan sejak dini bagi setiap individu maupun kelompok masyarakat, sehingga pancasila sebagai ideologi menjadi landasan pemikiran dan perilaku individu maupun sosial masyarakat. Oleh karena itu, pancasila diaktualisasikan dalam setiap bentuk tindakan masyarakat baik dalam hubungan hukum maupun hubungan sosial bermasyarakat. Kedudukan pancasila sebagai sumber dari segala sumber hukum negara diimplementasi dengan menempatkan nilai-nilai pancasila yang tidak hanya dijadikan sebagai sumber substantif dalam aspek-aspek hukum dan perundang-undangan. Sehingga pancasila menjadi cerminan perilaku masyarakat baik individu maupun kelompok masyarakat sesuai dengan nilai-nilai dasar dan pandangan hidup bersama sebagai bangsa dan negara Indonesia.

Pancasila sebagai falsafah atau ideologi negara oleh Rachmi Yulianti ${ }^{13}$ dapat dilihat dalam 2 (dua) sudut pandang, pertama dipahami secara normatif pancasila dijadikan sebagai acuan dalam segala tindakan. Kedua, dipahami secara filosofis dijadikan sebagai kajian atas nilai dan norma yang berkembang dimasyarakat. Dengan demikian pancasila memiliki kedudukan yang sangat berarti dalam sistem ketatanegaraan di Indonesia. Dengan berasumsi pada pemikiran tersebut jelaslah bahwa secara normatif nilai-nilai pancasila mempengaruhi karakteristik suatu kebijakan hukum dan/atau regulasi yang dibentuk oleh negara Indonesia. Rumusan pancasila sebagai falsafah Negara dapat menjaga kehidupan berbangsa dan bernegara dalam bingkai konsep demokrasi konstitusional yang dianut oleh Negara Indonesia. Pancasila sebagai ideologi Negara yang menjadi landasan dalam kehidupan berbangsa dan bernegara merupakan seperangkat nilai yang terdiri dari pandangan hidup (world view), nilai-nilai dan norma-norma yang menjadi cita-cita dan tujuan bangsa dan negara Indonesia. ${ }^{14}$

Konsepsi prinsip pancasila sebagai sumber segala sumber hukum berdampak pada sistem ketatanegaraan baik secara normatif maupun secara filosisfis. Secara tidak

\footnotetext{
${ }^{11}$ Tatu Afifah, Fuqoha Fuqoha, and Sukendar Sukendar, "Implikasi Ideologi Pancasila Pada Gerakan Sosial Islam Dalam Prinsip Demokrasi Konstitusional," Ajudikasi : Jurnal Ilmu Hukum 4, no. 2 (2020): 181-91, https://doi.org/10.30656/ajudikasi.v4i2.3003. hlm. 188

${ }^{12}$ Moh. Mahfud MD, Membangun Politik Hukum, Menegakkan Konstitusi, Cet. Ke-4 (Depok: Raja Grafindo Persada, 2017). hlm. 51

${ }^{13}$ Suryana Sudrajat and Abdul Malik, eds., Negara Darurat Etika, Cet. Ke-1 (Serang: Serabook, 2018). hlm. 454

${ }^{14}$ Eggi Sudjana, Islam Fungsional, Ed.1 (Jakarta: Rajawali, 2008). hlm. 128
} 
langsung keberadaan dan kedudukan pancasila sebagai falsafah negara memberikan pengaruh dalam penyelenggaraan negara termasuk terhadap kerangka hukum dan sistem hukum di Indonesia. Konsep pengaruh menurut Beddy Iriawan digambarakan dalam hubungan konsep kekuasan (power) dan konsep pengaruh (influence) bahwa pengaruh merupakan suatu bentuk kekuasaan secara filosofis maupun psikologis yang memberikan kesan/mempengaruhi seseorang atau orang lain. ${ }^{15}$ Dalam tatanan praktiknya terhadap implementasi politik hukum terhadap sistem hukum di Indonesia, Satjipto Rahardjo mendefinisikan politik hukum sebagai aktivitas memilih dan cara yang hendak dipakai untuk mencapai tujuan sosial melalui hukum. ${ }^{16}$ Dengan demikian karakteristik politik hukum bukan hanya terletak dan dipengaruhi oleh ideologi, akan tetapi juga dipengaruhi oleh proses terbentuknya kebijakan hukum yang akan diberlakukan tersebut.

Dinamika pengaruh terhadap cara dan proses perumusan suatu kebijakan hukum dalam kerangka politik hukum sebagaimana pemikiran Satjipto Rahardjo juga diungkapkan oleh Moh. Mahfud yang lebih ekstrim dengan menyebut hukum sebagai produk politik. Pemikiran tersebut didasarkan pada pemikiran K.C Wheare mengenai konstitusi bahwa peraturan perundang-undangan merupakan resultante (produk kesepakatan politik). ${ }^{17}$

Menelaah hukum sebagai produk politik sebagaimana dimaksud oleh Moh. Mahfud, maka perlu ditelaah sistem politik yang mempengaruhi dan merumuskan suatu kebijakan. Sistem politik diorientasikan pada gejala-gejala politik sebagai rangkaian proses yang mempengaruhi jalannya suatu sistem sosial oleh pelaku-pelaku politik. Dalam penjelasan Miriam Budiardjo mengenai konsep sistem politik diidentikan dengan konsep proses, struktur dan fungsi. ${ }^{18}$ Proses menunjukan pola hubungan antara satau sama lain dalam kerangka bernegara seperti parlemen, partai politik, birokrasi yang pada akhirnya pola hubungan sebagai proses tersebut akan membentuk struktur pelembagaan formal yang pada akhirnya memberikan kewenangan dalam kerangka hierarki pelembagaan sehingga setiap lembaga memerankan fungsi-fungsi tertentu seperti merumuskan kebijakan yang merupakan cita-cita dan tujuan masyarakat.

Tipologi sistem politik sangatlah beragam yang dipengaruhi dengan ideologi bangsa dan negara maupun sistem hukum yang diselenggarakan dengan berlandaskan pada konstitusi sebagai dasar negara hukum. Oleh karena itu, sistem politik di Indonesia dapat ditelaah melalui konstitusi sebagaimana diistilahkan oleh K.C Wheare

\footnotetext{
${ }^{15}$ Beddy Iriawan Maksudi, Sistem Politik Indonesia : Pemahaman Secara Teoretik Dan Empirik, 1st ed. (Jakarta: Rajawali Press, 2013). hlm. 87

${ }^{16}$ Ismatullah and Nurjanah, Op.cit. hlm. 23

${ }^{17}$ Moh. Mahfud MD, Politik Hukum Di Indonesia, Cet. Ke-4 (Jakarta: Rajawali Press, 2011). hlm. 6

${ }^{18}$ Miriam Budiardjo, Dasar-Dasar Ilmu Politik, Revisi (Jakarta: Gramedia Pustaka Utama, 2008). hlm. 57
} 
sebagai produk kesepakatan politik. Dilihat dari konsep sistem politik Indonesia dengan merujuk pada konstitusi, maka dapat dielaborasi dengan konsep negara hukum. Dimana konsep negara hukum menekankan pada peranan konstitusi sebagai landasan dasar bernegara. Dalam kerangka sistem politik yang dilandaskan pada konstitusi negara Indonesia, maka salah satu konsep dan/atau sistem politik adalah prinsip demokrasi. Prinsip demokrasi merupakan ciri dari konsep negara hukum, menurut J. Stahl dan Kant sering disebut dengan istilah rechtsstaat sedangkan A.V Dicey menyebutnya dengan istilah rule of law. ${ }^{19}$ Berlandaskan pada konsepsi negara hukum, baik konsepsi rechtsstaat maupun rule of law, maka hukum menjadi landasan yang menjadi kepastian hukum dan perlindungan hukum yang menjamin hak asasi manusia dalam pergaulan hidup bermasyarakat dalam prinsip demokrasi konstitusional.

Konsep rechtstaat dan rule of law menempatkan konstitusi sebagai landasan bernegara. Konstitusi menjadi dasar hukum tertulis yang paling tinggi dalam konsep negara hukum, sehingga konstitusi menjadi rujukan dasar atau sumber hukum dalam berbagai tindakan bernegara. Dengan demikian, prinsip demokrasi sebagai pilihan sistem politik di Indonesia memberikan ruang bagi masyarakat untuk terlibat dalam pemerintahan, termasuk dalam proses perumusan suatu kebijakan hukum.

Konsep politik sebagai interaksi antara pemerintah dengan masyarakat dalam rangka proses pembuatan dan pelaksanaan keputusan, merupakan bagian dari prinsip dan sistem demokrasi yang dianut bangsa dan negara Indonesia yang dikenal dengan istilah demokrasi konstitusional. Oleh karena itu, Moh. Mahfud menguraikan sistem politik mempengaruhi rumusan hukum dan pelaksanaan hukum sebagaimana istilahnya mengenai hukum sebagai produk politik. Pemikiran Moh. Mahfud bahwa suatu sistem politik dan/atau konfigurasi politik rezim akan mempengaruhi suatu produk hukum yang dilahirkan. Hal tersebut berimplikasi pada kenyataan bahwa negara dengan sistem politik demokratis akan menghasilkan produk hukum yang responsif, sedangkan negara dengan sistem politik otoriter, akan menghasilkan produk hukum yang konservatif. ${ }^{20}$

Konsepsi tersebut akan memberikan karakteristik pada produk hukum yang lahir dari keseimbangan kekuatan politik atau konfigurasi politik yang merupakan buah pemikiran politik yang dilakukan oleh politisi (Eksekutif dan/atau Legislatif). Moh. Mahfud mengasumsikan hubungan dasar politik dan hukum sebagai berikut : ${ }^{21}$

a) Hukum determinan atas politik dalam arti politik harus tunduk pada aturanaturan hukum, sehingga pergerakan politik seperti apapun harus sesuai dengan

\footnotetext{
${ }^{19}$ Jimly Asshidiqie, Hukum Tata Negara Dan Pilar-Pilar Demokrasi, Ed. Ke-2 (Jakarta: Sinar Grafika, 2012). hlm. 130

${ }^{20}$ Ismatullah and Nurjanah, Op.cit. hlm. 41

${ }^{21}$ Ibid.
} 
ketentuan yang ditetapkan. Oleh karena itu, hukum harus menyediakan seperangkat aturan main untuk semua kehidupan politik;

b) Politik determinan atas hukum dalam arti politiklah yang akan menentukan kehidupan hukum. Pemikiran ini didasari asumsi bahwa hukum adalah produk politik, sehingga substansi hukum merupakan hasil pemikiran (kristalisasi) dari kehendak-kehendak politik yang saling bersaing;

c) Antara hukum dan politik terjalin hubungan yang independen atau saling tergantung, dimana hukum dan politik mempunyai kedudukan atau kekuatan seimbang. Konsepsi hubungan tersebut bahwa hukum tanpa kekuasaan politik akan lumpuh dan sebaliknya politik tanpa kekuasaan hukum akan kesewenangwenangan.

Karakteristik politik hukum yang melahirkan identitas hukum nasional dengan berpatokan pada pemikiran Moh. Mahfud memiliki karakter yang saling berkaitan dengan keseluruhan tipologi tersebut. Pertama, konsepsi hukum lebih determinan itu dapat dilihat dari kekuasaan konstitusi yang membatasi segala kehendak politik yang merumuskan bahwa negara Indonesia berdasarkan pada rechtsstaat dan bukan machtsstaat menunjukkan bahwa hukum memiliki kedudukan yang lebih dominan daripada politik. Kedua, dalam tatanan praktik cenderung pada politik yang mendominasi hukum dengan melihat pada kontestasi eksekutif dan legislatif dalam merumuskan kebijakan-kebijakan hukum sebagaimana rezim kekuasaan tertentu yang berdampak pada pilihan-pilihan hukum yang akan diberlakukan oleh penguasa baik di eksekutif maupun di legislatif. Konsep politik lebih dominan dari pada hukum juga sejalan dengan pemikiran Satjipto Rahardjo ${ }^{22}$ bahwa suatu produk hukum sarat dengan warna politik (law as product of political process). Oleh karena itu, sulit menerjemahkan bagaimana karakteristik politik hukum di Indonesia dengan menggunakan pemikiran pertama dan kedua dari Moh. Mahfud.

Ketiga, menganalogikan hukum dan politik sebagai konsep yang saling bergantung satu sama lain sangatlah kompleks. Meskipun dikatakan bahwa hukum tanpa kekuasaan politik akan lumpuh dan politik tanpa hukum akan sewenangwenang, namun pada faktanya hukum tetap menjadi suatu komoditas bagi para pembentuk undang-undang dengan kekuasaanya merumuskan dan melahirkan suatu kebijakan hukum atau produk hukum disesuaikan dengan kebutuhan penguasa dalam rangka mencapai tujuan yang ditetapkan oleh penguasa (rezim).

Asumsi Moh. Mahfud mengenai hukum sebagai produk politik, dikonsepsikan beliau dengan memaknainya dengan kerangka dan analogi bahwa politik demokratis akan membuka peluang bagi peran dan potensi masyarakat secara maksimal untuk memberikan dan menentukan suatu kebijakan hukum yang akan diberlakukan.

${ }^{22}$ Ibid. 
Kemudian politik otoriter menempatkan pemerintah pada posisi yang dominan dengan sifat yang intervensionis dalam penentuan dan pelaksanaan kebijakan hukum. ${ }^{23}$

Konstitusi ekonomi sebagai landasan dasar dalam pemebntukan kebijakankebijakan politik hukum dibidang ekonomi tidak akan terlepas dari proses dan program-program yang ditetapkan oleh pemerintah yang berkuasa. Sehingga kebijakan hukum ekonomi dalam kerangka konstitusi ekonomi sebagaimana gagasan Jimly Asshiddiqie $^{24}$ sebagai suatu pendekatan hukum dan konstitusi pada bidang ekonomi dikarenakan ketidakpastiannya penyelenggaraan perekonomian nasional dalam mewujudkan kesejahteraan sosial.

Interpretasi terhadap konsepsi konstitusi ekonomi berbeda dengan ekonomi konstitusi dalam penelitiannya menjelaskan bahwa konstitusi ekonomi merupakan konstitusi yang di dalamnya memuat norma-norma dasar kebijakan ekonomi. Sedangkan ekonomi konstitusi adalah perekonomian berdasarkan konstitusi atau di sebut juga sebagai constitutional market economy. ${ }^{25}$ Maksud dari penafsiran tersebut bahwa konsep konstitusi ekonomi lebih pada kebijakan dasar dalam pembangunan sistem ekonomi nasional yang bersumber pada konstitusi dan sebagai sumber kontrol kekuasaan ekonomi. Sedangkan konsepsi ekonomi konstitusi hanya mewujudkan kebijakan hukum sebagai pengatur pelaksanaan perekonomian sebagai akibat dari konsep negara hukum.

Didasarkan pada konsepsi politik hukum yang diuraikan diatas, maka penulis berkesimpulan bahwa karakteristik politik hukum nasional yang didasarkan pada prinsip demokrasi konstitusional di Indonesia tercermin dalam kerangka yuridis normatif sebagaimana diatur dalam kerangka konstitusi dan peraturan perundangundangan. Namun demikian, dalam tatanan proses empiris pembentukan kebijakan hukum cenderung pada sifat otoriter yang memperlihatkan kekuasaan pemerintah baik eksekutif maupun legislatif. Sehingga identitas hukum nasional terwujud semi demokratis, dengan wujud produk hukum yang demokratis akan tetapi proses yang elitis dengan memaksakan kehendak penguasa dengan dasar ketercapaian tujuantujuan dan program-program pemerintah atau rezim penguasa. Amien Rais mengemukakan mengenai perbedaan format dan substansi demokrasi, bahwa appearance suatu sistem politik dapat terlihat demokratis, tetapi essence-nya sebenarnya otoriter. ${ }^{26}$

\footnotetext{
${ }^{23}$ Mahfud MD, Membangun Politik Hukum, Menegakkan Konstitusi. Op.cit. hlm. 67

${ }^{24}$ Jimly Asshiddiqie, "Memperkenalkan Gagasan Konstitusi Ekonomi," Jurnal Hukum Prioris Vol. 3, No. 2 (2013): 1-26, https://www.trijurnal.lemlit.trisakti.ac.id/prioris/article/view/360/330. hlm. 4

${ }^{25}$ Harvelian, Op.cit. hlm. 535

${ }^{26}$ Mahfud MD, Politik Hukum Di Indonesia, Op.cit. hlm. 11
} 


\section{Pengaruh Kekuasaan Politik Terhadap Program Legislasi Nasional Dalam Bidang Ekonomi}

Berbagai terminologi tentang politik hukum yang bermuara pada konsep legal policy mengenai kebijakan hukum yang akan diberlakukan atau tidak diberlakukan, yang selanjutnya politik hukum akan sangat dipengaruhi oleh sistem politik dan sistem hukum yang melandasi suatu politik hukum pada prinsipnya adalah suatu upaya bagi pemrintah dalam mewujudkan suatu pijakan dalam rangka mencapai cita-cita dan tujuan-tujuan negara. Oleh karena itu, tidak dapat dipungkiri sebagaimana pemikiran Sunaryati Hartono yang mengatakan bahwa hukum merupakan alat. ${ }^{27}$ Dengan demikian, maka politik hukum merupakan sarana pemenuhan alat-alat yang akan digunakan oleh pemerintah dan/atau penguasa dalam menciptakan suatu sistem hukum nasional guna mencapai cita-cita dan tujuan-tujuan bangsa dan negara Indonesia.

Cita-cita dan tujuan-tujuan bangsa dan negara merupakan suatu keniscayaan yang harus diperjuangkan oleh seluruh rakyat secara umum maupun pemerintahan (penguasa) secara khusus yang merepresentasikan kehendak-kehendak rakyat melalui proses demokratis. Pemerintahan memegang kendali dalam sistem tata pemerintahan sebagai bagian yang terbentuk dari sistem politik nasional. Konsep politik sebagai interaksi antara pemerintah dengan masyarakat dalam rangka proses pembuatan dan pelaksanaan keputusan, merupakan bagian dari prinsip dan sistem demokrasi. Namun dalam praktiknya, politik terkadang melampaui batasan-batasan sehingga seringnya politik mengintervensi terhadap pembentukan dan penerapan hukum nasional. Sehingga memunculkan suatu pertanyaan mengenai hubungan kekuasaan hukum dan kekuasaan politik dalam sistem ketatanegaraan. Moh. Mahfud ${ }^{28}$ mengkonstruksikan supremasi antara hukum dan politik, sehingga dapat diketahui landasan adanya intervensi politik terhadap hukum, maupun sebaliknya kekuasaan hukum terhadap politik.

Konteks supremasi hukum dan politik akan berdampak pada sistem hukum nasional, dimana oleh Lawrence Friedman sistem hukum akan terumuskan dalam 3 (tiga) unsur yang mendasar yaitu substansi atau isi hukum (substance), struktur hukum (structure), dan budaya hukum (culture). ${ }^{29}$ Bila unsur-unsur tersebut dikorelasikan dengan pengaruh (influence) dalam kerangka politik, dimana pengaruh dimaknai sebagai upaya mengubah sikap dan prilaku. ${ }^{30}$

Dengan mengelaborasi makna pengaruh dan politik yang dikorelasikan dengan sistem hukum sebagaimana konsepsi Lawrence Friedman maka dapat dimaknai

\footnotetext{
${ }^{27}$ Ismatullah and Nurjanah, Op.cit. hlm. 30

${ }^{28}$ Mahfud MD, Politik Hukum Di Indonesia. Op.cit. hlm. 9

${ }^{29}$ Mahfud MD, Membangun Politik Hukum, Menegakkan Konstitusi. Op.cit. hlm. 32

${ }^{30}$ Akbar Kaelola, Kamus Istilah Politik Kontemporer, Cet. Ke-1 (Yogyakarta: Cakrawala, 2009). hlm. 231
} 
sebagai suatu interaksi pemerintah dalam mengubah baik substansi atau isi hukumnya, kemudian struktur hukumnya maupun budaya hukum yang menjadi karakteristik sistem hukum nasional yang didasarkan pada kepentingan penguasa (rezim) menunjukkan supremasi politik terhadap hukum sangat dominan. Oleh karena itu, intervensionis politik terhadap hukum merupakan suatu keniscayaan yang tidak dapat dihindari dalam kerangka politik hukum nasional.

Pola hubungan hukum dan politik digambarkan oleh Nonet dan Selznik melalui 3 (tiga) kerangka hubungan, antara lain : ${ }^{31}$

1) Pola hubungan bersifat represif (repressive law)

2) Pola hubungan bersifat otonomi (autonomous law)

3) Pola hubungan yang bersifat responsive (responsive law)

Diuraikan oleh Nonet dan Selznik bahwa pola hubungan yang represif antara politik dan hukum menempatkan hukum sebagai bagian dari komoditas politik, sehingga hukum hanya dijadikan alat kekuasaan yang pada praktiknya menempatkan hukum dibawah kendali politik penguasa. Dengan demikian, baik substansi, struktur dan budaya hukum nasional diperbaiki, diubah, hingga diganti demi kepentingan politik, khususnya penguasa atas nama stabilitas maupun kepentingan negara. Pola hubungan otonom antara hukum dan politik memberikan kedudukan yang seimbang antara politik dan hukum, sehingga tidak ada yang lebih dominan antara hukum maupun politik. Sehingga hukum tidak diintervensi oleh politik dan dijadikan sebagai alat oleh kekuasaan yang represif. Konsepsi ini menunjukan adanya kekuasaan hukum terhadap politik sehingga terbentuknya suatu sistem hukum yang otonom.

Kerangka hubungan hukum dan politik yang paling ideal menurut Nonet dan Selznik adalah kerangka hubungan yang responsif. Konsepsi ini menempatkan hukum dan politik yang menciptakan suatu harmonisasi dan konsistensi pembentukan , penerapan dan penegakan hukum, meskipun terhadap kepentingan pemerintah (penguasa). Dengan demikian, pemerintahan akan senantiasa bersandar pada hukum, meskipun hukum merupakan produk politik pemerintah yang diciptakan untuk mengontrol prilaku politik pemerintahan dan masyarakat.

Berangkat dari konsepsi hukum dan politik oleh Nonet dan Selznik maka diarahkan pada politik pembangunan hukum nasional akan mengarah pada perencanaan pembangunan hukum yang termuat dalam Program Legislasi Nasional (PROLEGNAS). Sebagaimana dikemukakan sebelumnya bahwa politik hukum nasional dimaknai sebagai suatu kebijakan dasar penyelenggaraan negara Indonesia dalam bidang hukum yang akan, sedang dan telah berlaku, yang bersumber dari nilainilai yang berlaku di masyarakat untuk mencapai tujuan negara yang dicita-citakan.

\footnotetext{
${ }^{31}$ Samsul Wahidin, Politik Penegakan Hukum Di Indonesia, Cet. Ke-1 (Yogyakarta: Pustaka Pelajar, 2017). hlm. 76
} 
Dengan konsepsi Program Legislasi Nasional sebagai bentuk pemetaan dan perencanaan suatu kebijakan-kebijakan hukum dimasa yang akan datang. Moh. Mahfud MD mengemukakan bahwa Program Legislasi Nasional sebagai bentuk potret politik hukum. ${ }^{32}$ Hal tersebut menunjukkan bahwa program legislasi nasional merupakan bagian yang tidak terpisahkan dari hubungan politik dan hukum sehingga terbentuk kerangka konseptual politik hukum nasional.

Program legislasi nasional sebagai bentuk dan potret politik hukum disusun berdasarkan perencanaan eksekutif melalui Presiden dan pemerintahannya maupun Dewan Perwakilan Rakyat (DPR) yang pada kekuasaanya untuk menetapkan dan mengesahkan suatu rancangan hukum dengan proses sebagaimana diatur dalam perundang-undangan Nomor 12 Tahun 2011 tentang pembentukan peraturan perundang-undangan. Proses yang dilalui sampai dengan pengesahan suatu rancangan undang-undang tersebut yang memberikan proses politik hukum terhadap suatu kebijakan hukum.

Dalam praktik pelakasanaan program legislasi nasional, pemerintahan baik legislatif maupun eksekutif dapat mengarahkan dan memprioritaskan suatu kebijakan hukum sehingga politik hukum dapat mengarah pada intervensi dan pengaruh politik terhadap hukum yang akan diberlakukan oleh penguasa yang disesuaikan dengan kebutuhan hukum pemerintah (rezim penguasa). Hal tersebut yang kemudian menjadi asumsi Moh. Mahfud terhadap politik hukum yang menjadkan hukum sebagai produk politik.

\section{KESIMPULAN}

Dari uaraian singkat mengenai karakteristik politik hukum nasional dalam kerangkan konstitusi ekonomi, pada akhirnya menunjukkan bagaimana hubungan hukum dan politik sehingga terbentuk kerangka politik hukum sebagai suatu kajian keilmuan dalam hukum. Dilihat dari karakteristik politik hukum nasional tercermin dalam kerangka normatif sebagai sarana pembangunan dan pembaharuan hukum yang didasarkan pada konstitusi dan peraturan perundang-undangan. Namun demikian, secara proses bahwa pembentukan kebijakan hukum cenderung pada sifat otoriter yang memperlihatkan kekuasaan pemerintah baik eksekutif maupun legislatif. Sehingga identitas hukum nasional terwujud semi demokratis, dengan wujud produk hukum yang demokratis akan tetapi proses yang elitis dengan memaksakan kehendak penguasa dengan dasar ketercapaian tujuan-tujuan dan program-program pemerintah atau rezim penguasa. Pengaruh politik yang dominan sebagaimana diuraikan Nonet dan Selznik menjadi karakteristik hukum yang represif dalam pembentukan dan pembaharuan hukum nasional. Terlebih dalam rangka pembangunan hukum disusun melalui program legislasi nasional

${ }^{32}$ Mahfud MD, Membangun Politik Hukum, Menegakkan Konstitusi. Op.cit. hlm. 33 
yang dikatakan oleh Moh. Mahfud sebagai potret politik hukum. Dalam praktiknya pengaruh tersebut dapat mempengaruhi dan mengarahkan suatu program legislasi dengan menempatkan kebijakan hukum yang dianggap strategis kedalam program prioritas, dengan kata lain adanya intervensi kekuasaan politik terhadap hukum.

Konsepsi konstitusi ekonomi yang digagas oleh Jimly Asshiddiqie memberikan suatu pemikiran bahwa konstitusi sebagai landasan dasar dalam mewujudkan cita-cita dan tujuan bangsa dan negara sebagaimana dituangkan dalam undang-undang dasar 1945 harus mulai mengimplementasikan kekuasaan konstitusi dalam bidang ekonomi. Meskipun secara tersirat dalam undang-undang dasar 1945 telah diamanatkan, tetapi hal tersebut tetap dipengaruhi oleh politik hukum dan arah kebijakan politik hukum penguasa.

\section{DAFTAR PUSTAKA}

\section{Buku \& Jurnal}

Afifah, Tatu, Fuqoha Fuqoha, and Sukendar Sukendar. "Implikasi Ideologi Pancasila Pada Gerakan Sosial Islam Dalam Prinsip Demokrasi Konstitusional." Ajudikasi : Jurnal Ilmu Hukum Vol. 4, No. 2 (2020): 181-91. https://doi.org/10.30656/ajudikasi.v4i2.3003.

Asshiddiqie, Jimly. "Konstitusi Ekonomi (Ekonomi Pasar, Demokrasi Dan Konstitusi)." jimly.com,

2018.

http://www.jimly.com/makalah/namafile/164/Pengantar_Ekonomi_Konstitusi.pdf.

_. "Memperkenalkan Gagasan Konstitusi Ekonomi." Jurnal Hukum Prioris Vol. 3, No. 2 (2013): 1-26. https://www.trijurnal.lemlit.trisakti.ac.id/prioris/article/view/360/330.

Asshidiqie, Jimly. Hukum Tata Negara Dan Pilar-Pilar Demokrasi. Ed. Ke-2. Jakarta: Sinar Grafika, 2012.

Budiardjo, Miriam. Dasar-Dasar Ilmu Politik. Revisi. Jakarta: Gramedia Pustaka Utama, 2008.

Creswell, John W. Research Design, Pendekatan Kualitatif, Kuantitatif Dan Mixed. Third Ed. Yogyakarta: Pustaka Pelajar, 2015.

Harvelian, Agnes. "Mahkamah Konstitusi Dan Penguatan Konstitusi Ekonomi Indonesia." Jurnal Konstitusi Vol. 13, No. 3 (2016): 530. https://doi.org/10.31078/jk1333.

Ismatullah, Deddy, and Enung Nurjanah. Politik Hukum, Kajian Hukum Tata Negara. Cet. Ke-1. Bandung: Remaja Rosdakarya, 2018.

Jaya, Bergas Prana. Dasar-Dasar Pengantar Ilmu Hukum. Cet. Ke-1. Yogyakarta: Legality, 2019.

Kaelola, Akbar. Kamus Istilah Politik Kontemporer. Cet. Ke-1. Yogyakarta: Cakrawala, 2009.

Mahfud MD, Moh. Membangun Politik Hukum, Menegakkan Konstitusi. Cet. Ke-4. Depok: Raja Grafindo Persada, 2017.

—. Politik Hukum Di Indonesia. Cet. Ke-4. Jakarta: Rajawali Press, 2011.

Maksudi, Beddy Iriawan. Sistem Politik Indonesia: Pemahaman Secara Teoretik Dan Empirik. 1st ed. Jakarta: Rajawali Press, 2013. 
AJUDIKASI : Jurnal Ilmu Hukum, Volume 5 Nomor 2, Desember 2021. Hlm. 191-206

P-ISSN 2613-9995 \& E-ISSN 2614-0179

Purbacaraka, Purnadi, and M. Chidir Ali. Disiplin Hukum. Bandung: Citra Aditya Bakti, 1990.

Soekanto, Soerjono, and Sri Mamudji. Penelitian Hukum Normatif. Jakarta: Rajawali Press, 2006.

Sudjana, Eggi. Islam Fungsional. Ed.1. Jakarta: Rajawali, 2008.

Sudrajat, Suryana, and Abdul Malik, eds. Negara Darurat Etika. Cet. Ke-1. Serang: Serabook, 2018.

Syaukani, Imam, and A. Ahsin Thohari. Dasar-Dasar Politik Hukum. Cet. Ke-11. Depok: Rajawali Press, 2018.

Wahidin, Samsul. Politik Penegakan Hukum Di Indonesia. Cet. Ke-1. Yogyakarta: Pustaka Pelajar, 2017.

\section{Peraturan Perundang-Undangan}

Undang-Undang dasar Negara Republik Indonesia 1945

Undang-Undang Republik Indonesia Nomor 12 Tahun 2011 Tentang Pembentukan Peraturan

Perundang-Undangan 